\title{
"What We Do Every Day Is Impossible" : Managing Change by Developing a Knotworking Culture in an Academic Library
}

\section{Kaatrakoski, Heli}

2016-09

Kaatrakoski , H \& Lahikainen , J 2016 , ' "What We Do Every Day Is Impossible" : Managing Change by Developing a Knotworking Culture in an Academic Library ' , Journal of Academic Librarianship, vol. 42 , no. 5 , pp. 515-521 . https://doi.org/10.1016/j.acalib.2016.06.001

http://hdl.handle.net/10138/178233

https://doi.org/10.1016/j.acalib.2016.06.001

acceptedVersion

Downloaded from Helda, University of Helsinki institutional repository.

This is an electronic reprint of the original article.

This reprint may differ from the original in pagination and typographic detail.

Please cite the original version. 
Kaatrakoski, H., \& Lahikainen, J. (2016). "What We Do Every Day Is Impossible": Managing Change by Developing a Knotworking Culture in an Academic Library. The Journal of Academic Librarianship, 42(5), 515-521.

Heli Kaatrakoski and Johanna Lahikainen

\title{
"What we do every day is impossible": Managing Change by Developing a Knotworking Culture in an Academic Library
}

\begin{abstract}
Change, transformation, the reassessment of services and professional capabilities are key concepts in the language of academic libraries today. We suggest that two intertwined rationales - technical development and the marketisation of the public sector along with a customer approach - are driving the change that is challenging academic libraries to rethink their work and services. In this article, we first discuss embedded librarianship and knotworking in libraries as participatory approaches to the arrangement of academic library work and services. Second, we presented the findings of the Knotworking project and its follow-up interviews and suggest knotworking as a method with which librarians can collaboratively analyse their own work and develop services with researchers and thus respond to changing working environments. Third, we discuss changes in the work identity of librarians.
\end{abstract}

Keywords: knotworking, research support services, change laboratory, development

\section{Introduction}

Change, transformation, the reassessment of services and professional capabilities are key concepts in the language of academic libraries today. Needs to redefine librarians' work identity and library work has been raised in a number of studies worldwide (e.g. Hansson \& Johannesson, 2013; Jacobs \& Berg, 2013; McCluskey, 2013). In addition, academic librarians are challenged to engage with their researcher customers in new ways. Hansson and Johannesson (2013, p. 239) explain: "After a couple of decades of a strong customer-oriented ideology focusing on ever increasing numbers of undergraduate students, academic libraries in Sweden are now turning their interest back to their original patrons - the researchers."

In this article, we suggest that two intertwined rationales - technical development and the marketisation of the public sector along with a customer approach - are driving the change that is challenging academic libraries to rethink their work and services. Technical development in the 
forms of an increasing number of online services and digital publishing has been the leading promoter of change (Brindley, 2008). Technical developments have also affected the needs of students, researchers and faculty members. Collections of large research data, such as video or EEG (electroencephalography, brain activity) recordings, and the requirement of funding organisations for research lifespan plans and research data management plans create challenges for data management (Engeström et al., 2012).

Moreover, technical development and digital library collections have prompted researchers to 'escape' from academic libraries, freeing them from being merely physical users of academic libraries. While libraries appeal greatly to undergraduate students for whom they are an important physical space, postgraduates and researchers are moving away from them. Postgraduates and researchers no longer visit the library on a daily basis, but rather use the library's digital collections from a distance. When using the library's digital materials, they are often unaware of their origin and instead claim, as one of our librarian interviewees related to us, that they "do not need the library because they find everything they need from Google Scholar". Understandably, librarians are concerned that their meaning to researchers is diminishing and that therefore they need to innovate new services and new ways of working with researchers (Brindley, 2006; Engeström et al., 2012).

In the context of diminishing financial resources, the New Public Management ideology and the marketisation of the public sector have guided academic libraries to develop services and reframe their priorities (Hansson \& Johannesson, 2013). Conceptualising citizens and service users as customers and putting the primacy on end products instead of (learning) processes are embedded in this ideology (Clarke \& Newman, 2007; Edwards \& Daniels, 2012).

However, the adoption of a customer approach in public sector organisations can be challenging, since the objectives of commercial principles and the 'public good' are fundamentally different. Therefore a customer-oriented service approach may contest the old working methods and create conflicting situations in service encounters (Clarke \& Newman, 2007; Newman \& Vidler, 2006; Kaatrakoski, 2016). Along with a customer approach, the roles of librarians and even their identities must be redefined. Emphasis on the strengths of business concepts, such as the free market and individual choice, encourages movement toward an entrepreneurial society (Hood, 1991; Koskiaho, 2008), where the entrepreneurship of workers and the individualisation and automatisation of employees can be identified (du Gay, 1996). 
From the perspective of library work and librarians' identity, librarians are increasingly expected to master information technology; have commercial, legal and pedagogical knowledge; and acquire language and communication skills. They must be able to develop themselves and their work, master and tolerate change and new demands, be independent and proactive, have an entrepreneurial mindset, and be able to sell themselves. Therefore they constantly face challenges to learn new things and increase their expertise accordingly to emerging demands. In a nutshell, librarians are expected to be independent, self-directed, committed, enthusiastic and creative (Clyde and Lee, 2011, p. 169; Hyytiäinen, 2010, p. 166).

To sum up, library work has changed in that today librarians are service providers and learning practitioners whose object of work is serving customers. A shift from book-centric to customercentric work has been underway for some time (Brophy, 2007; Lossau, 2008; Scupola \& Nicolajsen, 2010). Instead of being reactive and passive actors, librarians are expected to be proactive and integrated into research work: to leave the library premises, forget the library jargon, meet customers elsewhere and innovate new services. They must have the "willingness and determination to meet users in their own environments, learning their terminologies and their languages, and wholehearted adoption of constructivist notions of how effective learning, and affective research, takes place. In other words librarians need to become much more visible and much more active in the learning and research processes. They need to embrace change" (Brophy, 2007, p. 523).

In this paper, we suggest knotworking as a method with which librarians can collaboratively analyse their own work and develop services with researchers and thus respond to changing working environments. We report on the empirical findings of the Knotworking in the Library development project (Knotworking project), which was conducted in the Helsinki University City Centre Campus Library in 2010-2011, and its follow-up interviews in 2014 (REMOVED 1)..

We ask how the method of knotworking was adopted in the library organisation. Did knotworking help the librarians to connect and engage with researchers? Did the Knotworking in the Library project have an impact on the new Helsinki University Library organisation implemented in 2014? How did the librarians conceptualise their work and work identity?

In the next section, we first review the approach of embedded librarianship, which has gained some attention in the literature as a participatory method with which to engage with library customers, especially researchers (Shumaker, 2009). We continue by introducing the knotworking method and discuss its benefits in work development and workplace learning in the context of academic 
libraries (Engeström et al, 2012). Later, we introduce the context of the study, the data and the findings. We finalise the paper with conclusions.

\section{Collaboration between librarians and researchers}

Only few studies have been done on participatory approaches, which report on collaboration between librarians and researchers or librarians as researchers as a part of research groups (Carlson \& Kneale, 2011; McCluskey, 2013). The emerging approach of the concept of embedded librarianship (Shumaker, 2009), developed in the United States, is probably the most known. To our knowledge it has not been used in the Finnish academic libraries in a systematic way; instead another approach with similar objectives, knotworking, has been tested and implemented at the University of Helsinki Library in Finland. Unlike embedded librarianship, the knotworking method has not been specifically developed to support library work, but work of multi-professional groups in the health care in Finland in the 1990s (Engeström, Engeström, \& Vähäaho, 1999). Ever since it was developed the method has been used in a number of different work settings.

In this paper we report on the empirical findings of the Knotworking project at the Helsinki University Library. At the time of the project the researchers responsible for the project were not familiar with the approach of embedded librarianship, but learnt about it afterwards.

The embedded librarianship approach provided the authors of this paper with interesting methods and observations, similar to knotworking. Therefore, we chose in this paper to discuss embedded librarianship and knotworking and create a dialogue between these approaches.

\section{Embedded librarianship}

Embedded librarianship is a built-in process in which librarians are increasingly more engaged in research activities and become partners with researchers and other members of researcher communities. The objective of building this partnership is to strengthen librarians' work identity as professionals and information specialists instead of as support officers and service providers operating in the background of research activities (Shumaker, 2009).

Carlson and Kneale (2011, p. 168) separate two types of embedded librarianship in research settings: project based and programmatic based. In the former model, the relationship between 
librarians and researchers develops gradually. In this process, librarians and researchers identify particular problems and attempt to solve them in collaboration. In the latter model, an organisation hires full-time librarians to perform defined responsibilities. In both cases, being an embedded librarian requires exiting the library premises and meeting customers in their own communities. Moreover, embedded librarianship is a form of providing customised services to a specific research community (Clyde \& Lee, 2011). Embedding can be employed in virtual environments and the community. The term 'community' encompasses both physical space and relationships (Carlson \& Kneale, 2011; Clyde \& Lee, 2011).

One example of embedding librarians in research communities is to arrange office hours in customers' premises, which can be later extended to more flexible working arrangements (Clyde \& Lee, 2011). Embedded librarians may take part in the research process in collection, management, the re-use and preservation of data, and documentation. In addition, embedded librarians can contribute to funding application processes as well as to the dissemination of research outcomes.

According to Clyde and Lee (2011), embedded librarianship can be a rather challenging method of working. It removes librarians "from the comfort zone" and familiar environments and places them in new contexts. Their study, however, suggested that exiting the library strengthened the relationship between librarians and their customers and facilitated integration into the research community. Moreover, the freedom given to librarians enabled them to design and deliver customised services in accordance with customers' needs. Since embedded librarianship is a new model or approach for most librarians, they lack tools and established methods for it, which makes it more difficult or even stressful (ibid.).

Shumaker (2009) argues that embedded librarianship is not an unproblematic approach. He introduces three critical points that may hinder its implementation:

1) The failure to allocate adequate funding and staff resources to both ongoing library services and the new embedded services.

2) The lack of established working methods to balance the workload between embedded and nonembedded librarians.

3) Overlooked threats to library staff cohesion.

Embedded librarianship can be conceptualised as a learning process in which the objective is to cocreate knowledge, that is, to learn (Arant-Kaspar \& vanDuinkerken, 2012). The literature review, however, did not reveal a theoretical basis for and conceptualisation of learning in the embedded 
librarianship approach. Further, embedded librarianship seemed to put an emphasis on library individuals and individual learning, even though the liaison with researchers in principle was introduced as a collective activity. Further, embedded librarianship was represented as a fixed or stable working method, not taking into account quickly changing work and service environments.

In the following section, we will first respond to the identified challenges and unanswered questions in the embedded librarianship approach. Second, we will introduce the knotworking method.

\section{Knotworking}

Knotworking is a working method and a learning process which has its roots in cultural-historical activity theory (Leont'ev, 1978; Vygotsky, 1978) and the theory of expansive learning (Engeström, 1987). The notion of knotworking refers to a negotiated way of working in which representatives of different organisations or units work on a specific task, which is a shared object, and collaboratively analyse their work; the collaboration forms 'knots'. Compared to teams, knots are less stable and fixed, thus making it possible to adapt to change more rapidly (Engeström, Engeström, \& Vähäaho, 1999). When circumstances change, new knots can and need to be formed accordingly. When individuals in a library context discuss their services it does not make it a knot. In knotworking different parties work on a specific object (data management services, for instance) and outline continuous actions to work on the object until the 'knot' is untied.

In the framework of cultural-historical activity theory, learning is conceptualised as a collaborative and object-oriented activity in which participants learn "something that is not there yet" (Engeström, 1987). Object orientation means that objects hold in themselves the motive which directs an activity. Thus, the object of the knot, for instance, not only refers to a material and physical object but also to its motive or purpose (Kerosuo, 2015, p. 203). Further, cultural-historical activity theory is a dialectical theory in which the concept of contradiction plays an important role (Il'enkov, 1982). Contradictions are historically evolved tensions in an activity, as well as sources of change, development and learning. Empirically observed conflicts in work can be explained with the concept of contradiction.

The practice of knotworking is typically initiated through the Change Laboratory organisation development method, which is based on developmental work research methodology (Engeström, 2007; Virkkunen \& Newnham, 2013). The Change Laboratory is a participatory and long-term development method designed to manage change and develop work. It starts by collecting mirror material in the form of interviews, recordings of work practices and documents in order to, for 
instance, trigger discussion during the sessions. Typically from five to ten participatory sessions are organised weekly in order to analyse the disturbances and challenges in the work and find solutions. Work practices are analysed with analytical tools such as the cycle of expansive learning and the activity system (Engeström, 1987, p. 323).

The idea of knotworking has been applied to a number of organisational settings, from health care, where it was originally tested (Engeström, Engeström, \& Vähäaho, 1999), to the building industry (Kerosuo et al., 2015). In this study, knotworking refers to a form of organising work in which librarians within or with their research group customers collaboratively analyse their work in order to develop library practices (Engeström et al., 2012).

Table 1 introduces the main characters and objectives of embedded librarianship (based on the literature review) and knotworking.

Table 1. Characters and objectives of Embedded Librarianship and Knotworking

\begin{tabular}{|l|c|c|}
\hline Characters and objectives & Embedded librarianship & Knotworking \\
\hline $\begin{array}{l}\text { Engagement with research } \\
\text { community }\end{array}$ & $\mathrm{x}$ & $\mathrm{x}$ \\
\hline Partnership with researchers & $\mathrm{x}$ & $\mathrm{x}$ \\
\hline $\begin{array}{l}\text { Strengthening librarian's } \\
\text { professional identity }\end{array}$ & $\mathrm{x}$ & $\mathrm{x}$ \\
\hline Learning process & $\mathrm{x}$ & $\mathrm{x}$ \\
\hline Co-creating knowledge & $\mathrm{x}$ & $\mathrm{x}$ \\
\hline $\begin{array}{l}\text { Challenging work method } \\
\text { Consideration of quickly changing } \\
\text { work and service environments }\end{array}$ & & $\mathrm{x}$ \\
\hline $\begin{array}{l}\text { Rapid adaptation to change } \\
\text { historical activity theory }\end{array}$ & & $\mathrm{x}$ \\
\hline $\begin{array}{l}\text { Theoretical background: } \\
\text { Expansive learning theory }\end{array}$ & & $\mathrm{x}$ \\
\hline $\begin{array}{l}\text { Methodology: Change laboratory } \\
\text { organisation development method }\end{array}$ & & \\
\hline
\end{tabular}




\begin{tabular}{|l|c|c|}
\hline $\begin{array}{l}\text { Used in library and information } \\
\text { sector }\end{array}$ & $\mathrm{x}$ \\
\hline $\begin{array}{l}\text { Used in several organisational } \\
\text { settings }\end{array}$ & & $\mathrm{x}$ \\
\hline
\end{tabular}

In this paper, we propose knotworking as a method to promote collaboration between librarians and researchers and enrich the embedded librarianship approach with specific focus on development, learning and adaption to change.

3. Knotworking in the Library: Context, Fieldwork and Data

The Knotworking in the Library project (Knotworking project) was a proactive development project carried out in the Helsinki University Library in Finland. In the Finnish context, libraries have been a leading actor in developing and implementing technical tools and a variety of e-materials in order to better serve their customers (e.g. Sinikara 2007; Hyytiäinen 2010, 165; Englund 2010, 103; Airio \& Ristikartano 2010). With the Knotworking project, the Helsinki University Library, however, took one step further when it recognised the need to develop not only tools, but also working practices in its rapidly changing environments. It is fair to say that the project is a pioneer in both Finland and worldwide in regard to analysing library work and developing work practices collaboratively with customers in academic library contexts.

The Knotworking project was conducted in the University of Helsinki City Centre Campus Library between the years 2010 and 2011. In the project, knotworking was initiated in weekly Change Laboratory sessions (8) and follow-up sessions (2). Prior to the sessions, librarians (4) and researchers (20) were interviewed.

First, the practical outcome of the project was the creation of a 'service tray', which eased the customisation of research services in accordance with customers' needs. Second, knotworking provided a learning space in which to create a new kind of working method between librarians and research groups. Third, it triggered a knotworking style of working inside the library organisation. Fourth, the project contributed to the new organisational structure in the City Centre Campus Library. For a detailed description of the process, see Engeström et al., (2012) and Engeström et al., (2013). 
Follow-up interviews (of six librarians and information specialists) were conducted approximately four years after the Change Laboratory sessions in the summer and autumn of 2014. The objective of the follow-up interviews was to record how the librarians had experienced the implementations and suggestions developed during the project. We asked the librarians their opinion of the Knotworking project four years after its implementation. From their perspective, what was the outcome? What was their opinion of the library's research services? What still needed to be done in order to improve the services? The data was analysed using thematic categorisation.

\section{Findings of the study}

The findings of the study can be divided into four intertwined, but here analytically separated topics:

1) Knotworking among librarians: how was knotworking used in daily work and service development?

2) Knotworking with researchers: how was knotworking used in the interaction between the librarians and researchers?

3) Developing a new knotworking organisation model: did the project influence organisational changes, and if it did, how?

4) Building librarians' identity: how did the project shape the professional identity of librarians?

In this article we put primacy on the follow-up interviews conducted in 2014, but data collected during the actual project is also included in the reporting.

The overall view was that participating in the Knotworking project was rewarding and fruitful. It gave the librarians tools to interact and engage with researchers in novel ways. The findings in the follow-up interviews suggest that, on one hand, what was developed was implemented in practice but, on the other hand, that the profound introduction of the new working methods had not been successful. The need to continue with knotworking and to develop services further with the researchers was evident in the data:

Welcome or good riddance to the knot, there really is a reason to ponder how to create this system here in the library. It was kind of forgotten when we came here [moved to the new library building]. There has happened so much and so many things, but the knot should not be forgotten, and now we should think quickly how we can get a working connection and liaison with the department. 
Knotworking was an excellent method of working. I am probably one of them in the library who remembers this very warmly and thinks that we must get something like this going again. The library cannot invent those things alone. We are not the best experts. [...] It has been a very new way to develop library services.

In the following section, the findings are discussed in more detail.

\section{Knotworking among Librarians}

In 2014, during the follow-up interviews, the knotworking way of working could still be identified inside the City Centre Campus Library:

We have used the word knot rather readily after those years [after the Knotworking project] in the work meetings. Like just meaning something like that or as an alternative term for a working group, a kind of bunch of folks gathering around an issue when necessary.

However, knotworking had not been applied throughout the organisation in a systematic way. Those engaging in knotworking and referring to knotworking were mainly the librarians who had participated in the project, but the interviewees explained that some other colleagues had adopted the approach, too. This observation reveals the dissemination of the knotworking way of working to some extent within the work community. Some participants felt that the project only gave a name to working methods that had been used prior to the project and thus did not necessarily produce anything new:

Or maybe that kind of working method was given a name. It is probably not used by everyone [in the library]. Because there were only some of us involved in that knot. Because the ones who participated remember it and use the name knot. If I think that the definition is an informal group put together to solve a certain issue and functions for a short time and with a clear aim, then we did do it quite a lot before, too.

Those who recognised the importance of knotworking emphasised its strength in quick problem solving, which had been absent in the prevailing working culture. They saw the necessity of creating a new and dynamic working environment, which would be possible with knotworking. One of the interviewees suggested that the knotworking way of working would enable needed development leaps. From a larger perspective, the project had provided an upper hand in the negotiations regarding the research service development for those librarians who had participated in the Knotworking project. They had been able to concretise the research customers' needs instead of guessing and making decisions based on a general discourse: 
With the implementation of the new tool [LibGuides], we have had long conversations about this [the role of the research support services] and like [name] said the knot has worked in that sense. And it has been easy for me to advance it. Because I have always been able to say that we have learned already before, we already know that researchers act like this. And that we do this primarily for researchers. Because I said that for the library it is very easy and traditional to think about any service from the point of view of a common client. [...] So I would say that one of the benefits of the knot has been that we have been able to concentrate on the researcher client and been able to learn from them something that can be used also in the library's internal discussions.

\section{Knotworking with Researchers}

The realisation of knotworking methods was more visible inside the organisation than in the work with research customers. In general, knotworking was explained to be an interesting and novel way of meeting with research groups, but was considered a rather heavy method to be implemented similarly to how it was conducted during the project (the Change Laboratory sessions). In addition, direct contact with research groups had not been realised in the ways which were planned in the sessions. Rather, the contact was described as "juggling" and was only implemented with individuals.

The Knotworking project, however, supported the librarians' professional identity and encouraged the librarians to move outside of their comfort zone and approach researchers as professionals.

For me, it gave courage, [previously] I didn't know how it would be best to co-operate with researchers. We had a long process together when we were in that knot. I got kind of a partnership thinking with researchers.

The librarians felt that the project had been a reciprocal learning process: they had increased their understanding of researchers' work and needs, and some of the research groups were more enthusiastic about testing new services after the project.

Further, the librarians had started to work proactively to respond to researchers' needs; for instance, the awareness of current services was developed. The future orientation was, however, questioned by one of the participants:

At the moment the library is always running behind, the university and researchers are far ahead and the library guesses what they might need. We should plan more and get the researchers involved in the planning. And make them engage with us without feeling that they have to, voluntarily, but how. I don't know. [...] One of the reasons why we run after them is our image. According to this image, we are supposed to be running after them, but this isn't so. 
Her statement suggested that innovations in the Knotworking project remained partly unimplemented. She saw the library rather as following researchers instead of as being able to provide services in a professional way. Her suggestion was to systematically liaise with researchers, but was uncertain of what would be the best method for such voluntary collaboration. Some suggestions of how to build up a relationship, such as participating in seminars and other events, were identified in the data. McCluskey (2013, p.7), however, warns that such participation still refers to librarians as support people rather than as equal professionals.

The interviewees saw the necessity of having more systematic follow-up work regarding the infrastructure and rapidly changing tools used by the researchers. Questions regarding Open Access, digital repositories, research data management and new developments in the disciplinary field were raised as upcoming learning challenges for librarians. Therefore, the continuation of the Knotworking project would be very much called for and appreciated. One of the participants explained:

I would see that kind of larger knot which is given plenty of work hours, I do think it is a good or one possible method of action that should be carried out in the library. Because earlier I said that we do need information from multiple sources. Like an evidence-based working method, in information literacy it has been talked about a lot, but in everything else too. Let's say like a refined gut feeling. To put it in a fancier way, combining this kind of long expert experience and the scientific knowledge found in articles. Then statistical information and then information from contacts, for instance, research groups. So then you could say that if, for example, all this shows that something works, then there would be quite much evidence there. However, many things are done by ear.

Unlike what had been planned, the knotworking approach was not disseminated and applied in other campus libraries. This lack of implementation was most likely connected to the large changes underway in the library organisation during and after the project. Further, it became evident that not everyone agreed on the novelty of the new knotworking method and the results of the project. In some libraries, such activities were already in use on a daily basis:

For us [in our library unit] it was a bit strange thing this knot. That we were gobsmacked for a long time, what they are saying. Like collaboration with the department. We were looking at each other because we did it every day.

The importance of knotworking was, however, recognised, since moving to the new library building had changed the physical proximity of librarians and researchers. Thus, the need for systematic working methods for interacting with researchers was addressed a number of times. 


\section{The New Knotworking Organisation}

The Helsinki University Library was reorganised in 2015. The new organisation is divided into three service units: Learning Services, Research Services and Access Services. From the perspective of Research Services, the aim of the reorganisation was to establish a shared frame for research service provision in each campus of the University of Helsinki. Although it would be an exaggeration to say that the Knotworking project had a direct impact on the reorganisation of the library, according to the current Research Support Services Director, the project provided support for establishing a new department for research services.

As reported earlier, the knotworking way of working with research groups was not realised as intensively as planned. The follow-up interviews, however, revealed that the reorganisation provided the opportunity to proceed toward the library's strategic aims and increase liaisons with research group customers. One emphasised aspect was the strengthening of the library's identity as a professional organisation, especially the position of research services as an identified entity in the library organisation:

In this renewing organisation, there of course are research services, so I have thought that their importance and visibility can grow. And of course it will be easier to develop cooperation because we will be a lump with outlines, not an amoeba. Because we have this one identified silo. Outwards we should appear that we are available. We are an entity with a shape. Like when some researcher or group or someone wonders what help, what guidance is possible to get from the library, it will click into the [right] place at once. The things we can give. Who to contact and where when I want [something]. There will be an immediate answer. Because now it isn't so.

Moreover, the reorganisation was expected to provide the opportunity to create working methods which would support the librarians' proactive agency and their ability to follow research trends in order to offer services to researchers in a systematic way. On one hand, research services were described as including managing and delivering an extensive amount of information. On the other hand, they were described as intensive collaboration with researchers. Since the provided services move between these two dimensions, "guessing what researchers' needs are", as was described by one of the interviewees, is not sufficient in the prevailing culture.

Knotworking Supporting the Development of the Library Professionals’ Identity

Along with developing library services, the identity of librarian was one of the topics discussed during the project and the follow-up interviews, even though it was not particularly brought up by 
the researchers. Since the preservation and delivery of material are no longer the core of library work, new capabilities and a "new" understanding of librarians as professionals were explained to be needed. Because the interviewees pondered the question of identity, it seems that that there is an urgent need to strengthen the librarians' professional identity.

The findings in the data revealed that librarians compared their work and working methods with research work and researchers. First, they increasingly encountered the need to strengthen their professionalism and equality in regard to their research customers. Suggested steps toward the change were explained to be gained, for instance, by doing practice-based research on their own activity, collecting best practices from other academic libraries worldwide and being proactive in service provision. One of the project participants explained:

And then also I have been pondering a lot there, when researchers are in question, equality. Like how we can advance professionally into a level that we are interesting interlocutors to the researchers. And it does not necessarily happen that we ask what you need. But we should be really able to offer something, show something. Like hey, this is what's going on, this could help you.

The university library is dependent on its mother organisation, its resources and strategies, and therefore can be conceptualised as a supporting agent. But the library is also a professional organisation, whose experts need to be seen as equal to researchers. In many cases, librarians do not see themselves as interesting interlocutors with researchers.

Second, finding a balance between the "new" customer-oriented service organisation and the "old" book-reserving organisation was identified in the data. Further, the conduction of a project such as Knotworking in the Library was understood inside the organisation not entirely as a positive effort to meet emerging challenges but also was seen as a platform in which librarians were weak service providers fulfilling researchers' wishes:

I remember that some members of library staff denigrated the knot ideology because there one went to ask researchers, like hey we in the library don't know what to do, like please tell us, and we, cap in hand, carry out everything you might wish for in that particular moment. Like it was seen in the wrong way, that we appeared as weak and not as experts. But in my opinion it doesn't have to mean that at all, but the intention was particularly to combine library expertise and practical needs.

The aim of the project was, however, to link together librarians and researchers in order to systematically develop something new as a joint effort. 
Third, the descriptions of prevailing and especially unsystematic working methods paralleled librarians' work with the pursuit of a hobby or depicted them as working during their own time on individual interests on top of their "own, real work". For example, librarians keep current on new library trends and the changing work environment on their own time. Such dedication and commitment were understood to initiate from the university culture, which was adopted in the library context. They wished that they had work hours allocated for these tasks so that this would not be a "hobby":

When we at the same time anyway do work duties, not hobbies. That it sometimes feels a bit strange. That it comes from the university as a working environment. Like partly we have this researcher attitude and it is just like that we can think there is administration and researchers. And administration tries to command researchers to act in a certain way.

In the excerpt above, the librarians were performing a balancing act between an identity as a researcher and that of an administration or support service person. This was seen as a problem, especially for research support services.

In the following excerpt, the researcher attitude was also brought up. It was described as challenging since the approach does not always promote the aims of the library organisation:

One does things with an individual researcher attitude, but it doesn't always lead to us doing effectively what is expected from the library. I see that we are not sole traders and free agents, but we ought to also do the things that are expected from the library. As sensibly, fast and efficiently too, as possible.

As the excerpt above revealed, librarians should not work as entrepreneurs or free actors, which might ignore the larger objectives of library work. At its worst, this researcher identity in librarians leads to behaviour which interviewees called being an "absent-minded professor", as the following example shows. These librarians were well integrated in the research community, but their ambitions were individual, not part of the library's collective objectives:

On one hand, I spoke of an assistant's identity, but some have had this absent-minded professor identity. They follow things and do research and are next to the researchers, but in a way that their goals aren't the house goals. It is grand but maybe that too should change $[\ldots]$ the expert who works for shared goals.

Some of the librarians were seen as too individualistic and as insufficiently identifying with their employer and colleagues in the library. Instead, their identification was rooted in the researcher community. 
This balancing act of being a librarian in the university library has led librarians to identify themselves as entrepreneurs and consultants, yet as equal with researchers. How this differs from a traditional work identity was found in the data:

It must be a huge change that you should keep track of what happens and adopt and assess it and maybe pass it on. A really huge change compared to that if people have come to work in the way that they are going to preserve some things. Or take care of and such. And then if the work identity suddenly should be like, here one is a consultant.

Librarians are expected to offer something instead of only asking what customers' needs are. One of the challenges in service provision was the fact that sometimes customers do not recognise their needs, thus placing more responsibility on the library professional in the service encounters. Librarians not only need to be active, but to be proactive.

This demand to be proactive, "a new librarian", can induce enthusiasm, but often also stress and anxiety (Hyytiäinen 2010, 165-166). One of the interviewees said that, on one hand, librarians may feel that the new role is too demanding or even impossible, but on the other hand, it is not; they are managing the situation:

It probably sounds like we would be breaking down in front of the challenges. Like, they are too big. But, I don't know. What we do every day is impossible.

\section{Discussion}

In this article, we first discussed embedded librarianship and knotworking in libraries as participatory approaches to the arrangement of academic library work and services. Second, we presented the findings of the Knotworking project and its follow-up interviews. Embedded librarianship and knotworking are both methods of working in which librarians and researchers collaborate intensively. They differ in that knotworking not only refers to working methods, but the development dimension and a future orientation are also emphasised in the approach. Therefore, it is simultaneously a platform for a dynamic working environment and sphere for developing work and services that are needed in quickly changing environments. Similar elements can also be identified in project-based embedded librarianship, but not in such a profound way as in knotworking (Carlson \& Kneale, 2011, p. 168). Further, in embedded librarianship, collaboration with researchers was important, but an individual working method was emphasised. In knotworking, the librarians work together as a group with both each other and researchers. From the 
learning point of view this is important, since there is a vast amount of evidence of the benefits of collective learning (Hager, 2011).

Shumaker (2009) has identified three critical points in the embedded librarianship approach, resource allocation being one of them. In the Knotworking project, the Helsinki University Library decided to follow one of the library's strategic goals and focus on research group customers instead of individual researchers, thus responding to decreasing resources.

The findings in the data showed that the Knotworking project had influenced library work in a positive way, but that the change had not necessarily been sustainable. The need and relevance to continue a project such as Knotworking in the Library or its application was mentioned by some participants. For example, librarians were explained to be in a key position in research service development and provision. To overcome their prevailing individual and incidental way of working, large-scale systematic procedures were urgently needed to support their work.

The changes in librarians' work and work identity received extensive attention in the data. There were a number of references to a shift in the work identity of librarians toward the style of working of an autonomous consultant or entrepreneur and to the necessity of managing a variety of different tasks due to the digitisation of material. In addition, a service orientation and the balance between service to customers and the duties of a librarian were brought up. Similar changes can be identified in other fields of work, and therefore we suggest that they relate to larger market-oriented changes in society, which may have larger implications than official discourses may lead us to think (Needham, 2006; Newman \& Vidler, 2006; Clarke \& Newman, 2007; Kaatrakoski, 2016). One of the implications is the individualisation and autonomisation of work (du Gay, 1996). The combination of increasingly independent and autonomous working methods and quickly changing work environments calls for support in the development of librarians' work identity. Instead of the end products of learning and development, learning processes must be emphasised. This requires further longitudinal studies and in-depth analyses.

This study has several limitations. The article is descriptive, and a deep qualitative analysis was not conducted; therefore more research is needed to further analyse learning and changes in librarians' work and work identity. One focal challenge they encountered when liaising with researchers was motivating the researchers to collaborate. This study does not respond to that challenge, and more field research is needed to chart the opportunities and possibilities for collaboration. Finally, critical voices toward the Knotworking project were lacking in this paper. They were present in the data of the development sessions, but not in the follow-up interviews. 


\section{Acknowledgements}

We wish to thank the Helsinki University Center for Properties and Facilities, all the library staff, and the interventionists who participated in the Knotworking in the Library project in the Helsinki University Library in 2010-2011. The project was financed by the Helsinki University Center for Properties and Facilities. We are especially indebted to Professor Yrjö Engeström, Professor Kaisa Sinikara, Service Director Pälvi Kaiponen, Director of Sector Anna-Maija Lukkari, Director Teppo Salmikivi, Head Architect Eija Vuori, Heli Myllys, Anne Laitinen, and, Juhana Rantavuori. We are grateful to the follow-up interviewees: without you this article would not exist. This article is dedicated to the memory of information specialist and literary scholar and critic Lasse Koskela (1955-2015), whom we all miss. 


\section{REFERENCES}

Airio, E. \& Ristikartano, V. (2010). Digitaalinen arkisto edistää yliopistollisen tutkimuksen avoimuutta ja jatkokäyttöä [Digital Repository promotes open access and reuse of academic research] In K. Sinikara, M. Forsman, I. Karppinen, \& P. Lammi (Eds.). Rajapinnassa. Uusi Helsingin yliopiston kirjasto (pp. 119-128). Helsinki: Helsinki University Library

Arant-Kaspar, W., \& vanDuinkerken, (2012). Be the Change: Librarian as a Learning Organism. The Journal of Academic Librarianship, 38(4), 189-190.

Brindley, L. (2008). The International Dimensions of Digital Science and Scholarship: Aspirations of the British Library in Serving the International Scientific and Scholarly Communities. In R. Earnshaw, \& J. Vince (Eds.) Digital Convergence-Libraries of the Future, (pp. 65-105). London: Springer. doi:10.1007/978-1-84628-903-3

Brophy, P. (2007). Communicating the library: librarians and faculty in dialogue. Library Management, 28(8/9), 421-433. doi: 10.1108/01435120710837792

Carlson, J., \& Kneale, R. (2011). Embedded librarianship in the research context. Navigating new waters. College \& Research Libraries News, 72(3), pp. 167-170.

Clarke, J., \& Newman, J. (2007). What's in a Name? New Labour's citizen-consumers and the remaking of public service. Cultural Studies, 21(4-5), 738-757. doi:10.1080/09502380701279051

Clyde, J., \& Lee, J. (2011). Embedded Reference to Embedded Librarianship: 6 Years at the University of Calgary. Journal of Library Administration, 51(4), pp. 389-402.

Du Gay, P. (1996) Consumption and Identity at Work. London: Sage.

Edwards, A., \& Daniels, H. (2012). The knowledge that matters in professional practices. Journal of Education and Work, February 2012, 25(1), 39-58. doi:10.1080/13639080.2012.644904

Engeström, Y. (1987). Learning by expanding: An activity-theoretical approach to developmental research. Helsinki: Orienta-konsultit.

Engeström, Y. (2007). Putting Vygotsky to work: The change laboratory as an application of double stimulation. In H. Daniels, M. Cole, \& J.V. Wertsch (Eds.), The Cambridge companion to Vygotsky (pp. 363-382). Cambridge: Cambridge University Press.

Engeström, Y., Engeström, R., \& Vähäaho, T. (1999). When the center does not hold: the importance of knotworking. In S. Chaiklin, M. Hedegaard, \& U.J. Jensen (Eds.). Activity Theory and Social Practice: Cultural-Historical Approaches (pp. 345-374). Aarhus: Aarhus University Press.

Engeström, Y., Kaatrakoski, H., Kaiponen, P., Lahikainen, J., Laitinen, A., Myllys, H., Rantavuori, J., \& Sinikara, K., Knotworking in academic libraries: two case studies from the University of Helsinki, Liber Quarterly: The Journal of European Research Libraries, 21 (3/4), 2012, 387-405, http://liber.library.uu.nl/index.php/lq/article/view/URN:NBN:NL:UI:10-1-113636

Engeström, Y., Rantavuori, J., \& Kerosuo, H., Expansive learning in a library: Actions, cycles and deviations from instructional intentions, Vocations and Learning, 6 (1), 2013, 81-106. 
Englund, J. (2010). Asiakaslähtöiset verkkopalvelut - esimerkkinä Meilahden kampuskirjasto Terkko [Customer-Oriented Online Services - Meilahti Campus Library as an Example Case]. In K. Sinikara, M. Forsman, I. Karppinen, \& P. Lammi (Eds.). Rajapinnassa. Uusi Helsingin yliopiston kirjasto (pp. 101-107). Helsinki: Helsinki University Library.

Hager, P. (2011). Theories of Workplace Learning. In M. Malloch, L. Cairns, K. Evans, \& B. N. O'Connor (Eds.), The SAGE Handbook of Workplace Learning (pp. 17-31). London: Sage.

Hansson, J., \& Johannesson, K. (2013). Librarians' views of academic library support for scholarly publishing: An every-day perspective. Journal of Academic Librarianship, 39(3), 232-240. doi:10.1016/j.acalib.2013.02.002

Hood, C. (1991). A public management for all seasons? Public Administration, 69(1), 3-19. doi:10.1111/j.1467-9299.1991.tb00779.x

Hyytiäinen, E. (2010). Joustaa, joustaa... Henkilöstö muutoksessa [Being flexible, being flexible. Personnel in transformation]. In K. Sinikara, M. Forsman, I. Karppinen, \& P. Lammi (Eds.). Rajapinnassa. Uusi Helsingin yliopiston kirjasto (pp. 165-172). Helsinki: Helsinki University Library.

Il'enkov, E. V., The Dialectics of the Abstract and the Concrete in Marx's Capital, 1982, Progress; Moscow.

Jacobs, H. L., and Berg, S. A., By librarians, for librarians: Building a strengths-based institute to develop librarians' research culture in Canadian academic libraries, Journal of Academic Librarianship, 39 (3), 2013, 227-231.

Kaatrakoski, H. (2016). Conceptualising Customers in the Public Sector: An Activity-theoretical Analysis. Helsinki: University of Helsinki.

Kerosuo, H., BIM-based Collaboration Across Organizational and Disciplinary Boundaries Through Knotworking, Procedia Economics and Finance, 21, 2015, 201-208.

Kerosuo, H., Mäki, T., \& Korpela, J. (2015). Knotworking and the visibilization of learning in building design. Journal of Workplace Learning, 27(2), 128-141.

Koskiaho, B. (2008). Hyvinvointipalvelujen tavaratalossa: Palvelutalous ja sosiaalipolitiikka Englannissa, Ruotsissa ja Suomessa [In a department store of welfare services: service economy and social politics in Great-Britain, Sweden, and Finland]. Tampere: Vastapaino.

Leont'ev, A.N., Activity, Consciousness and Personality, 1987, Prence-Hall; Englewood Cliffs.

Lossau, N. (2008). Digital services in academic libraries: The internet is setting benchmarks. In R. Earnshaw, \& J. Vince (Eds.) Digital Convergence-Libraries of the Future, (pp. 11-30). London: Springer. doi:10.1007/978-1-84628-903-3

McCluskey, C. (2013). Being an embedded research librarian: supporting research by being a researcher. Journal of Information Literacy, 7(2), pp. 4-14.

doi: http://dx.doi.org/10.11645/7.2.1815

Needham, C.E. (2006). Customer Care and the Public Service Ethos. Public Administration, 84(4), 845-860. doi:10.1111/j.1467-9299.2006.00615.x 
Newman, J., \& Vidler, E. (2006). Discriminating Customers, Responsible Patients, Empowered Users: Consumerism and the Modernisation of Health Care. Journal of Social Policy, 35(2), 193209. http://dx.doi.org/10.1017/S0047279405009487

Scupola, A., \& Nicolajsen, H. W. (2010). Service innovation in academic libraries: Is there a place for the customers? Library Management, 31(4), 304-318. doi:10.1108/01435121011046362

Shumaker, D. (2009). Who Let the Librarians Out? Embedded Librarianship and the Library Manager. Reference \& User Services Quarterly 48(3), pp. 239-242.

Sinikara, K. (2007). Ammatti, ihminen ja maailmankuva murroksessa: Tutkimus yliopistokirjastoista ja kirjastonhoitajista tietoyhteiskuntakaudella 1970-2005 [Profession, Person and Worldview at a Turning Point: A Study of University Libraries and Library Staff in the Information Age 1970 - 2005]. Helsinki: University of Helsinki, Faculty of Theology, Department of Comparative Religion. http://urn.fi/URN:ISBN:978-952-10-4251-5

Virkkunen, J., \& Newnham, D.S. (2013). The change laboratory: A tool for collaborative development of work and education. Rotterdam: Sense Publishers.

Vygotsky, L.S., Mind in Society. The Development of Higher Psychological Processes, 1978, Harvard University Press; London. 